\title{
Histomorphometric Study of the Proportion of Different Zones of Adrenal Cortex - A Postmortem Study
}

\author{
Dilruba Siddiqua ${ }^{1}$,Abu Sadat Mohammad Nurunnabi ${ }^{2}$, Fatema Johora ${ }^{3}$, Hasna Hena ${ }^{4}$, Sunjida \\ Shahriah $^{5}$, Shamim Ara ${ }^{6}$
}

\begin{abstract}
Background: The human adrenal cortex shows a distinct proportion of three zones, named zona glomerulosa, zona fasciculate \& zona reticularis, from outer inwards, in its histological appearance with differences in its cellular components and functions. Objective: The aim of the present study was to see the variation in the proportion of zones of the adrenal cortex in different age-group in a Bangladeshi population. Methods: This cross-sectional, descriptive study was done in the Department of Anatomy, Dhaka Medical College, Dhaka, from July 2008 to June 2009, based on collection of 140 post mortem human adrenal glands from 70 unclaimed dead bodies which were in the morgue under examination in the Department of Forensic Medicine, Dhaka Medical College, Dhaka. The samples were divided into four age-groups including A (11-20 years), B (21-30 years), C (31-40 years) \& D (41-60 years). Histological slides were prepared by using routine haematoxylin and eosin stain (H \& E). Five best prepared slides from each group were examined under light compound microscope with low magnification. The thickness of different layers adrenal cortex were measured by using ocular and stage micrometer and then converted into percentage volume. Results: The mean volume of the zona glomerulosa, zona fasciculata and zona reticularis of the right adrenal cortex were found $14.16 \pm 0.79 \%, 78.40 \pm 1.14 \%, 7.44 \pm 0.52 \%$ in group A; $14.58 \pm 0.38 \%, 78.00 \pm 0.71 \%, 7.42 \pm 0.38 \%$ in group $B ; 14.34 \pm 0.83 \%, 78.56 \pm 0.52 \%, 7.30 \pm 0.50 \%$ in group $C$; $14.08 \pm 1.23 \%, 78.80 \pm 1.10 \%, 7.10 \pm 0.22 \%$ in group $\mathrm{D}$ respectively. The mean volume of the zona glomerulosa, zona fasciculata and zona reticularis of the left adrenal cortex were found $14.66 \pm 0.34 \%, 78.84 \pm 0.82 \%$, $7.72 \pm 0.48 \%$ in group $\mathrm{A} ; 14.62 \pm 0.30 \%, 78.54 \pm 0.84 \%, 7.58 \pm 0.43 \%$ in group $B ; 14.90 \pm 0.96 \%, 79.20 \pm 0.45 \%$, $7.34 \pm 0.42 \%$ in group $\mathrm{C} ; 14.70 \pm 1.25 \%, 79.40 \pm 0.55 \%, 7.30 \pm 0.35 \%$ in group D respectively. Conclusion: No difference was found statistically significant in the percentage volume of the three zones of the adrenal cortex with advancing age in Bangladeshi people.
\end{abstract}

Key words: Human adrenal gland, adrenal cortex, zona glomerulosa, zona fasciculata, zona reticularis.

Bangladesh Soc Physiol. 2014, December; 9(2): 89-93

For Authors Affiliation, see end of text.

http://www.banglajol.info/index.php/JBSP

\section{Introduction}

7 he adrenal gland is composed of two distinct portions i.e. an outer cortex (mesodermal origin) and an inner medulla (neuroectodermal origin) ${ }^{1}$. Because of the differences in disposition and appearance of

Received May 2014; $\quad$ Accepted October 2014 its cells, the adrenal cortex can be subdivided into three concentric layers, whose limits are not sharply defined in humans. From outer inwards, the layers are named as zona glomerulosa, zona fasciculata and zona reticularis ${ }^{2}$. Zona glomerulosa consists of small columnar cells arranged in rounded clusters (glomeruli) and curved columns that are continuous with the 
cords of cells in the zona fasciculata. In humans, however, zona glomerulosa may be absent in some areas of the cortex ${ }^{3}$. Zona fasiculata consists of large polyhedral cells arranged in parallel columns of cords, usually one or two cells' thick; these columns are separated by the sinusoids ${ }^{4}$. Zona reticularis, the thin innermost layer, consists of an irregular network of branching cords and clusters of glandular cells separated by numerous wide diameter capillaries; these glandular cells are much smaller than those of adjacent zona fasciculata ${ }^{5}$. The cortical zones of the adrenal glands are very distinct in their histological appearance with difference in cellular components as well as in their functions. Several evidences suggest that the volume of different adrenal cortical layers are also indicators of functional state of the gland and influenced by aging, alcohol consumption, stress and systemic disease $^{6-10}$. Therefore, a sound knowledge on proportion of different cortical zones of the adrenal gland is essential for clinical decision making in endocrinology, pathology, radiology and surgery for better diagnosis and management of diseases of adrenal cortex. The present study was aimed to see the variation in the proportion of zones of the adrenal cortex with advancing age in a Bangladeshi population and compare with the previous studies and available text references.

\section{Methods}

A cross-sectional, descriptive study was done in the Department of Anatomy, Dhaka Medical College, Dhaka, from July 2008 to June 2009, to see the variation in the proportion of the different zones of adrenal cortex in different age-groups in a Bangladeshi population. The study was based on collection of 140 post mortem human adrenal glands collected from 70 unclaimed dead bodies which were in the morgue under examination in the Department of Forensic Medicine, Dhaka Medical College, Dhaka. All the samples were collected within 24-36 hours of death without any sign of putrefaction and taken from medicolegal cases excluding poisoning, any cutting or crushing injury to the adrenal glands, and adrenal glands found in one side and diseased. The present study was approved by the Ethical Review Committee of Dhaka Medical College, Dhaka.

Grouping of the Sample: For convenience of the study, the collected samples were divided into four age-groups including A(11-20 years), B (2130 years), C (31-40 years) \& D (41-60 years), according to Kangarloo et al. ${ }^{11}$.

Procedure of histological study: The tissue blocks of the adrenal glands were fixed in $10 \%$ formol saline in a plastic container. The tissues were washed in running tap water, dehydration was done with ascending grades of alcohol, cleared with xylene, infiltrated and embedded in paraffin. Paraffin blocks were cut at $5 \mathrm{~mm}$ thickness and were stained with routine Harris' Haematoxylin and Eosin (H \& E) stain. All the measurements were taken by using an Olympus CHB light microscope, made in Tokyo, Japan. At first, the thickness of all three zones of the adrenal cortex were determined (Figure 1). For measuring the thickness of three zones of the adrenal cortex 5 best prepared slides were selected from each group. Hence, a total of 20 slides were examined high magnification (' 40 objectives, ' 10 eyepiece).

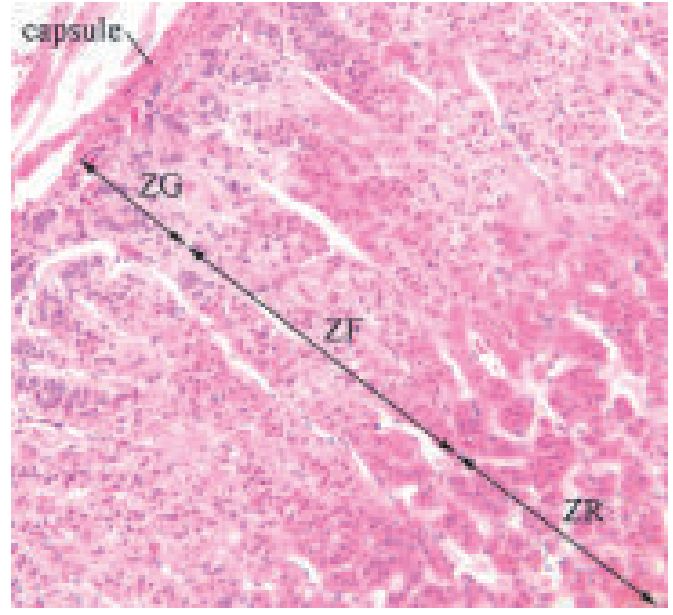

Figure 1. Photomicrograph of the human adrenal gland showing the extent of three zones of adrenal cortex, taken from group C (31-40 years). From outer inwards: $\mathrm{ZG}=$ Zona Glomerulosa, $\mathrm{ZF}=\mathrm{Zona}$ Fasciculata and ZR $=$ Zona Reticularis $(\times 400$ magnification) ( $\mathrm{H} \& \mathrm{E}$ stain). 
Three different fields were chosen for measuring the thickness from each slide. The thickness was measured by using a stage micrometer and an ocular micrometer. Three measurements were taken for each slide and the average was recorded. The stage micrometer calibration was focused under the objective to be used and the ocular micrometer calibration was superimposed on them in such a way that starting mark on the ocular micrometer matched exactly with a starting mark on the stage micrometer. Then the marker on the stage and ocular micrometer that corresponds to each other most closely was noted. Then determination of how many of the smallest division of the ocular micrometer corresponded with how many smallest division of the stage micrometer was done, according to Nurunnabi et al. ${ }^{12}$. After getting the thickness in ìm, it was converted into percentage proportion which signifies percentage volume of the zones of the adrenal cortex as well.

Statistical processing of data: The data collected were processed and statistical analyses were done by using SPSS version 13.0. The comparison between the right and the left was done by unpaired Student's ' $t$ ' test and comparison between age groups by One-way ANOVA.

\section{Results}

Right adrenal gland: The mean volume of the zona glomerulosa, zona fasciculata and zona reticularis of the right adrenal cortex were found $14.16 \pm 0.79 \%, 78.40 \pm 1.14 \%, 7.44 \pm 0.52 \%$ in group $\mathrm{A} ; 14.58 \pm 0.38 \%, 78.00 \pm 0.71 \%, 7.42 \pm 0.38 \%$ in group B; $14.34 \pm 0.83 \%, 78.56 \pm 0.52 \%, 7.30 \pm 0.50 \%$ in group $\mathrm{C} ; 14.08 \pm 1.23 \%, 78.80 \pm 1.10 \%$, $7.10 \pm 0.22 \%$ in group D respectively (table I).

Left adrenal gland: The mean volume of the zona glomerulosa, zona fasciculata and zona reticularis of the left adrenal cortex were found $14.66 \pm 0.34 \%$, $78.84 \pm 0.82 \%, 7.72 \pm 0.48 \%$ in group $\mathrm{A}$; $14.62 \pm 0.30 \%, 78.54 \pm 0.84 \%, 7.58 \pm 0.43 \%$ in group B; $14.90 \pm 0.96 \%, 79.20 \pm 0.45 \%, 7.34 \pm 0.42 \%$ in group $\mathrm{C} ; 14.70 \pm 1.25 \%, 79.40 \pm 0.55 \%, 7.30 \pm 0.35 \%$ in group D respectively (table I). However, the differences of the percentage volume of the three zones of the adrenal cortex of both right and left sides were not statistically significant in among the groups.

Table I: Percentage volume of three zones of right and left adrenal cortex in different age group

\begin{tabular}{|c|c|c|c|}
\hline \multirow[t]{2}{*}{ Age grol } & \multicolumn{3}{|c|}{$\begin{array}{l}\text { Percentage volume }(\%) \\
\text { Right adrenal cortex }\end{array}$} \\
\hline & $\begin{array}{l}\text { Glomerulosa } \\
\text { Mean } \pm \text { SD }\end{array}$ & $\begin{array}{c}\text { Fasciculata } \\
\text { Mean } \pm \text { SD }\end{array}$ & $\begin{array}{l}\text { Reticularis } \\
\text { Mean } \pm \text { SD }\end{array}$ \\
\hline $\mathbf{A}$ & $14.16 \pm 0.79$ & $78.40 \pm 1.14$ & $7.44 \pm 0.52$ \\
\hline$(\mathrm{n}=5)$ & $(13.00-15.00)$ & $(77.00-80.00)$ & $(7.00-8.00)$ \\
\hline B & $14.58 \pm 0.38$ & $78.00 \pm 0.71$ & $7.42 \pm 0.38$ \\
\hline$(n=5)$ & $(14.00-15.00)$ & $(77.00-79.00)$ & $(7.00-8.00)$ \\
\hline $\mathrm{C}$ & $14.34 \pm 0.83$ & $78.56 \pm 0.52$ & $7.30 \pm 0.50$ \\
\hline$(\mathrm{n}=5)$ & $(13.00-15.00)$ & $(78.00-79.00)$ & $(7.00-8.00)$ \\
\hline D & $14.08 \pm 1.23$ & $78.80 \pm 1.10$ & $7.10 \pm 0.22$ \\
\hline$(\mathrm{n}=5)$ & $(12.50-15.00)$ & $(78.00-80.00)$ & $(7.00-7.50)$ \\
\hline \multirow{2}{*}{$\begin{array}{l}\text { Age } \\
\text { group }\end{array}$} & \multicolumn{3}{|c|}{ Left adrenal cortex } \\
\hline & $\begin{array}{c}\text { Glomerulosa } \\
\text { Mean } \pm \text { SD }\end{array}$ & $\begin{array}{l}\text { Fasciculata } \\
\text { Mean } \pm \text { SD }\end{array}$ & $\begin{array}{l}\text { Reticularis } \\
\text { Mean } \pm \text { SD }\end{array}$ \\
\hline A & $14.66 \pm 0.34$ & $78.84 \pm 0.82$ & $7.72 \pm 0.48$ \\
\hline$(n=5)$ & $(14.20-15.00)$ & $(78.20-80.00)$ & $(7.20-8.40)$ \\
\hline B & $14.62 \pm 0.30$ & $78.54 \pm 0.84$ & $7.58 \pm 0.43$ \\
\hline$(n=5)$ & $(14.20-15.00)$ & $(77.90-80.00)$ & $(7.20-8.30)$ \\
\hline $\mathbf{C}$ & $14.90 \pm 0.96$ & $79.20 \pm 0.45$ & $7.34 \pm 0.42$ \\
\hline$(\mathrm{n}=5)$ & $(13.50-16.00)$ & $(79.00-80.00)$ & $(7.00-8.00)$ \\
\hline D & $14.70 \pm 1.25$ & $79.40 \pm 0.55$ & $7.30 \pm 0.35$ \\
\hline$(n=5)$ & $(13.00-16.00)$ & $(79.00-80.00)$ & $(7.00-7.80)$ \\
\hline
\end{tabular}

Figures in parentheses indicate range.

Group A (11-20 years), Group B (21-30 years), Group C (31-40 years), Group D (41-60 years).

\section{Discussion}

Fawcett $^{2}$ stated that from outer inwards, zona glomerulosa, zona fasciculata and zona reticularis constitute $15 \%, 78 \%$ and $7 \%$ of the total volume of the cortex respectively in humans. Bocian- 
Sobkowska ${ }^{13}$ studied on 40 adrenal glands obtained from children between $1^{\text {st }}$ and $370^{\text {th }}$ day during autopsy. The postnatal decrease in the adrenal volume is mainly caused by rapid fall of the fetal zone volume (from $70 \%$ to $3 \%$ of total adrenal volume). Involution was accompanied by increase of zona glomerulosa (from 10-25\% of the total adrenal volume), zona fasciculata (from $10-38 \%$ ) and zona reticularis volume (from 1$23 \%$ ). However, during the whole investigated the volume of the medulla remained constant. According to Maitra ${ }^{14}$, the outer zona glomerulosa is approximately $10-15 \%$, zona fasciculata is about $80 \%$ and zona reticularis is about $5-10 \%$ of the total cortical volume. Barrett et al. ${ }^{15}$ reported that the zona glomerulosa makes up $15 \%$ of the mass of the adrenal gland; the zona fasciculata $50 \%$; and the zona reticularis $7 \%$. Hall ${ }^{16}$ stated that the zona glomerulosa constitutes about $15 \%$ of the adrenal cortex, the middle widest portion, zona fasciculata, is about $75 \%$ and zona reticularis, the deep layer is about $10 \%$ of the adrenal cortex. According to Ross \& Pawlina ${ }^{3}$, zona glomerulosa, the narrow outer zone constitutes $15 \%$, while zona fasciculata, the thick middle zone is nearly $80 \%$, and zona reticularis, the inner zone, is only $5-7 \%$ of the cortical volume. Mescher ${ }^{1}$ reported that the outer zona glomerulosa is about $15 \%$, zona fasciculata is about $65 \%$ and zona reticularis is about $7 \%$ of the total volume of the adrenal gland. Gartner \& Hiatt ${ }^{4}$ mentioned that the outer zona glomerulosa constitutes approximately $13 \%$, zona fasciculata is about $80 \%$ and zona reticularis is about $7 \%$ of the total cortical volume. In the present study, on an average, zona glomerulosa was found $14.08-14.90 \%$, while zona fasciculata and zona reticularis were found $78.00-79.40 \%$ and 7.10 $7.72 \%$ respectively in human adrenal cortex. Our autopsy based findings are more or less similar to those of previous studies and text references. However, there is no previous study in our country on proportion of the cortical zones of human adrenals, as to compare with the present study.

J Bangladesh Soc Physiol. 2014, December; 9(2): 89-93

\section{Conclusion}

No difference was found statistically significant in the percentage volume of the three zones of the adrenal cortex with advancing age in Bangladeshi people. To the best of our knowledge, this is the first ever study in our country on determining the proportion of different zones of the cortical portion of the adrenal gland. However, further studies with larger samples and advanced stereological techniques are recommended. The results of the present study can be used as a standard reference for the adrenal glands of Bangladeshi people and to determine the abnormal evidences in pathological cases.

\section{Acknowledgement}

We would like to express our gratitude to the authority of Health, Nutrition \& Population Sector Programme (HNPSP) of Directorate General of Health Services (DGHS) of the Government of the People's Republic of Bangladesh, and Dhaka Medical College, Dhaka, for providing us with the research grant to support this study.

1. * Dr. Dilruba Siddiqua, Associate Professor, Department of Anatomy, Ibn Sina Medical College, Dhaka. Email: shekhor19@yahoo.com

2. Dr. Abu Sadat Mohammad Nurunnabi, Assistant Professor, Department of Anatomy, OSD, Directorate General of Health Services (DGHS), Dhaka.

3. Dr. Fatema Johora, Assistant Professor, Department of Anatomy, OSD, Directorate General of Health Services (DGHS), Dhaka.

4. Dr. Hasna Hena, Associate Professor, Department of Anatomy, East West Medical College, Dhaka.

5. Dr. Sunjida Shahriah, Associate Professor, Department of Anatomy, Z.H. Sikder Women's Medical College, Dhaka.

6. Prof. Shamim Ara, Professor \& Head, Department of Anatomy, Dhaka Medical College, Dhaka.

*For correspondence

\section{References}

1. Mescher AL. ed. Junqueira's basic histology: text and atlas. $13^{\text {th }}$ ed. New York: McGraw-Hill; 2013: p.414-8. 
2. Fawcett DW. Bloom \& Fawcett - a textbook of histology. $12^{\text {th }}$ ed. New York: Chapman \& Hall; 1994: p.503-15.

3. Ross MH, Pawlina W. Histology: a text and atlas with correlated cell and molecular biology. $6^{\text {th }} \mathrm{ed}$. Baltimore: Lippincott Williams \& Wilkins; 2011: p.762-70.

4. Gartner LP, Hiatt JL. Color atlas and text of histology. $6^{\text {th }}$ ed. Baltimore: Lippincott Williams \& Wilkins; 2014: p.246-8.

5. Young B, Lowe JS, Stevens A, Heath JW. Wheater's functional histology: a text and colour atlas. $5^{\text {th }}$ ed. Edinburgh: Elsevier Churchill Livingstone; 2006: p.338-41.

6. Grant CS. Surgical anatomy of the thyroid, parathyroid, and adrenal glands. In: Fischer JE, Bland KI, Callery MP, Clagett GP, Jones DB, LoGerfo FW, et al. eds. Mastery of surgery. Vol. 1. $5^{\text {th }}$ ed. Philadelphia: Lippincott Williams \& Wilkins; 2007: p.394-7.

7. Rebuffat P, Belloni AS, Rocco S, Andreis PG, Neri G, Malendowicz LK, et al. The effect of ageing on the morphology and function of the zonae fasciculata and reticularis of the rat adrenal cortex. Cell Tissue Res 1992; 270(2): 265-72.

8. Monsefi M, Bahoddini A, Nazemi S, Dehghani GA. Effects of noise exposure on the volume of adrenal gland and serum levels of cortisol in rat. Iran J Med Sci 2006; 31(1): 5-8.

9. Meier J, Iruvuri S, Saad Alzeair S, Houseni M, Alavi A, Torigian D. Structural and functional changes in the adrenal glands with age as determined by FDG-PET and CT imaging. J Nucl Med 2007; 48(Suppl 2): 67.

10. Grant LA, Napolitano A, Miller S, Stephens K, McHugh SM, Dixon AK. A pilot study to assess the feasibility of measurement of adrenal gland volume by magnetic resonance imaging. Acta Radiol 2010; 51(1): 117-20.

11. Kangarloo H, Diament MJ, Gold RH, Barrett C, Lippe B, Geffner M, et al. Sonography of adrenal glands in neonates and children: changes in appearances with age. J Clin Ultrasound 1986; 14(1): 43-7.

12. Nurunnabi ASM, Mahbub S, Shahriah S, Begum GN, Ara S. Thyroid follicles and parenchyma are found to increase with advancing age during the first 50 years of life in Bangladeshi people. J Bangladesh Soc Physiol 2009; 4(2): 88-92.

13. Bocian-Sobkowska J. Morphometric study of the human suprarenal gland in the first postnatal year. Folia Morphol 2000; 58(4): 275-84.

14. Maitra A. The endocrine system. In: Kumar V, Abbas AK, Fausto N, Aster JC. eds. Robbins and Cotran pathologic basis of disease. $8^{\text {th }}$ ed. New Delhi: Elsevier Saunders; 2010: p.1148-61.

15. Barrett KE, Barman SM, Boitano S, Brooks HL, eds. The adrenal medulla \& adrenal cortex. Ganong's review of medical physiology. $23^{\text {nd }}$ ed. New York: McGraw-Hill; 2010: p.337-61.

16. Hall JE. Adrenocortical hormones. In: Guyton and Hall: textbook of medical physiology. $12^{\text {th }}$ ed. Philadelphia: Saunders Elsevier; 2011: p.921-4. 